\title{
PENYULUHAN KESEHATAN TENTANG PENCEGAHAN COVID-19 DAN PEMERIKSAAN KESEHATAN DI DESA IMBUDEE KECAMATAN KUTABLANG KABUPATEN BIREUEN
}

\author{
Siti Saleha ${ }^{1}$, Nurhidayati ${ }^{2}$, Zulfa Hanum ${ }^{3}$ \\ 123 Dosen Program DIII Kebidanan Universitas Almuslim \\ Email: saleha89aly@gmail.com,nurhidayatiibrahim64@gmail.com, \\ zulfahanum89@gmail.com
}

\begin{abstract}
ABSTRAK
Corona virus atau virus corona merupakan keluarga besar virus yang menyebabkan infeksi saluran pernapasan atas ringan hingga sedang, seperti penyakit flu. Banyak orang terinfeksi virus ini, setidaknya satu kali dalam hidupnya. Namun, beberapa jenis virus corona juga bisa menimbulkan penyakit yang lebih serius. Sampai saat ini terdapat corona virus (HCoVs) yang telah diidentifikasi, salah satunya adalah Covid-19 atau dikenal juga dengan Novel Coronavirus (menyebabkan wabah pneumonia di Kota Wuhan, Tiongkok pada Desember 2019). Indonesia sendiri mengumumkan adanya kasus Covid tanggal 19 dari Maret 2020. Siapa pun dapat terinfeksi Virus Corona. Akan tetapi, bayi dan anak kecil, serta orang dengan kekebalan tubuh yang lemah lebih rentan terhadap serangan virus ini. Selain itu, kondisi musim juga berpengaruh. Contohnya, di Amerika Serikat, infeksi virus corona lebih umum terjadi pada musim gugur dan musim dingin. Tujuan pengabdian dalam bentuk penyuluhan tentang pencegahan Covid-19 di Desa Imbudee adalah dengan meningkatkan pemahaman tentang cara menjaga jarak, memakai masker dan mencuci tangan dengan benar. Adapun hasil yang diperoleh setelah pelaksanaan kegiatan adalah peningkatan pemahaman masyarakat tentang cara pencegahan wabah Covid-19.
\end{abstract}

Kata Kunci: $\quad$ corona virus, covid-19, penyuluhan

\begin{abstract}
Corona virus is a family of viruses that cause mild to moderate upper respiratory tract infections, such as flu. Many people are infected with this virus, at least once in their life. Until now there have been identified coronaviruses (HCoVs), one of which is COVID-19 or also known as the Novel Coronavirus (which caused an outbreak of pneumonia in the city of Wuhan, China in December 2019). Indonesia itself announced the initial case of covid 19 on March 2020. Anyone can be infected with the corona virus. However, babies and young children, as well as people with weak immunity are more susceptible to this virus attack. In addition, seasonal conditions may also have an effect. For example, in In the United States, corona virus infections are more common in autumn and winter. The aim of this service has been carried out in the form of counseling about the prevention of Covid-19 in Imbudee Village is to increase the understanding of how to keep the distance, to wear the masks and to wash hands properly. The results obtained after the implementation of the activity were an increase in public understanding of how to prevent the Covid-19 outbreak. The output of this community service activity was in the form of articles published in the ISSN community service journal.
\end{abstract}

Key Words : corona virus, counseling, covid-19 


\section{PENDAHULUAN}

Mewabahnya penyebaran penyakit Corona Virus Diseases-19 atau dikenal dengan Covid-19 menyebabkan bencana bagi masyarakat hingga mengakibatkan kematian ribuan jiwa di seluruh dunia, tidak terkecuali di Indonesia. Munculnya wabah penyakit ini mendorong pentingnya untuk memberikan edukasi terhadap masyarakat tentang Perilaku Hidup Bersih dan Sehat (PHBS). Selain itu, masyarakat perlu mengetahui dengan pasti penularan dan cara pencegahan Covid-19 agar tidak terus mewabah. Masyarakat juga disarankan untuk tinggal di rumah, menggunakan masker, karyawan bekerja dari rumah (Work From Home/WFH), mencuci tangan dan menerapkan PHBS.

PHBS merupakan salah satu starategi dalam pencegahan penyebaran Covid-19 yang sangat efektif dan mudah dilakukan oleh semua lapisan masyarakat. Masyarakat dihimbau untuk meningkatkan prilaku hidup bersih dan sehat dalam upaya pencegahan penyebaran Covid-19, karena perilaku masyarakat sangat berperan penting dalam penurunan angka penyebaran Covid-19. Pemerintah terus menghimbau gerakan PHBS menjadi kunci pencegahan penyebaran Covid-19 pada masa pandemik ini. Sehingga, diharapkan penyebaran Covid-19 dapat dihambat dan tidak bertambah. Oleh karena pentingnya perilaku hidup bersih dan sehat, perlu dilakukan pemberian informasi secara terus menerus sehingga dapat meningkatkan pengetahuan seluruh lapisan masyarakat untuk menerapkan PHBS dalam kehidupan sehari-hari.

Data Kementerian Kesehatan per 24 November 2020, Indonesia mengalami penambahan pasien terkonfirmasi positif harian bertambah sebanyak 4.192 kasus. Untuk jumlah kumulatif atau pasien yang tercatat terkonfirmasi positif sejak kasus pertama hingga saat ini berjumlah 506.302 kasus. Sementara jumlah kasus aktif, yakni pasien Covid-19 yang masih menjalani masa perawatan atau kasus aktif Covid-19, per hari ini berjumlah 64.878 kasus atau 12,8\% dari pasien terkonfirmasi. Pada kasus pasien meninggal harian juga masih bertambah sebanyak 109 kasus dan kumulatifnya menjadi 16.111 kasus atau 3,2\% dari pasien terkonfirmasi. Selain itu, per hari ini jumlah suspek tercatat ada 64.414 kasus dan spesimen selesai diperiksa sebanyak 39.971 spesimen. Untuk sebaran wilayah masih berada di 34 provinsi dan 505 kabupaten/kota. 
Berdasarkan rincian per provinsi, penambahan kesembuhan tertinggi berada di DKI Jakarta dengan 1.060 kasus dan kumulatifnya mencapai 117.969 kasus. Diikuti Jawa Barat menambahkan pasien sembuh sebanyak 428 kasus dan kumulatifnya mencapai 40.452 kasus. Urutan ketiga di Jawa Tengah dengan menambahkan 300 kasus dan kumulatifnya menjadi 36.051 kasus. Jawa Timur urutan keempat kesembuhan harian, dengan menambahkan sebanyak 157 pasien sembuh harian, namun kumulatifnya masih kedua tertinggi mencapai 52.546 kasus. Lalu, Kalimantan Timur masuk ke urutan lima menambahkan kesembuhan dengan 132 kasus dan kumulatifnya 15.903 kasus.

Kegiatan pengabdian ini memiliki tujuan umum untuk memberikan pemahaman kepada masyarakat tentang wabah penyebaran Covid-19 dan PHBS merupakan starategi yang dapat mencegah penyebaran Covid-19. Adapun luaran yang diharapkan dari penyuluhan ini adalah menghasilkan luaran yang akan dipublikasikan pada jurnal pengabdian masyarakat ber-ISSN baik cetak maupun online.

\section{METODE PELAKSANAAN}

Tahap awal kegiatan pengabdian ini dimulai dengan penjajakan untuk mengetahui jumlah masyarakat Desa Imbudee. Kegiatan penyuluhan kesehatan tentang pencegahan Covid-19 dan pemeriksaan kesehatan gratis kepada masyarakat dilaksanakan dengan cara memberikan penyuluhan tentang pencegahan Covid-19 dengan mencuci tangan, memakai masker dan jaga jarak, perilaku hidup bersih dan sehat, serta melakukan pemeriksaan kesehatan gratis kepada masyarakat.

Teknik pelaksanaan kegiatan adalah dengan menentukan jadwal kegiatan dilakukan, lalu memberitahukan melalui pengumuman yang disampaikan oleh kepala desa. Alat dan bahan yang dipakai pada pemeriksaan glukosa darah dan asam urat yaitu melalui pemeriksaan laboratorium berupa pemeriksaan glukosa darah dan asam urat menggunakan set pemeriksaan autocheck dan perlengkapan lainnya seperti HCL 0,1, kapas alkohol, pipet, lanset steril, larutan aquadest, nierbeken dan handscoon. Kegiatan pegabdian masyarakat ini dilaksanakan di Desa Imbudee Kecamatan Kutablang Kabupaten Bireuen, pada tanggal 19 Oktober s.d 07 November 2020, yang dimulai dari 
penjajakan lahan, penentuan jadwal kegiatan dan pembuatan laporan. Adapun penyuluhan dan pemeriksaan kesehatan ini dilakukan di Polindes Desa Imbudee.

\section{HASIL DAN PEMBAHASAN}

Hasil dari pelaksanaan kegiatan pengabdian kepada masyarakat yang dilakukan oleh dosen dan mahasiswa program Diploma III Kebidanan Universitas Almuslim yaitu yang pertama sekali melakukan koordinasi dengan Kepala Desa yaitu Bapak Iskandar, S.Pd bahwa kegiatan ini dilaksanakan di Desa Imbudee dengan melibatkan peserta yang yang merupakan masyarakat Desa Imbudee yang ingin mengikuti penyuluhan dan pemeriksaan kesehatan gratis. Lalu, melakukan koordinasi bidan desa setempat untuk pemeriksaan gula darah dan asam urat, jika ada hasil pemeriksaan yang tidak sesuai maka dilakukan dengan menggunakan alat pemeriksaan kesehatan. Memberikan penyuluhan pencegahan Covid-19 yaitu dengan jaga jarak, penggunaan masker dan mencuci tangan dengan benar serta pemeriksaan gula darah dan asam urat kepada masyarakat Desa Imbudee sebanyak 27 orang.

Kegiatan pengabdian ini berjalan dengan baik, masyarakat sangat antusias dalam mendengarkan penyuluhan dan melakukan pemeriksaan kesehatan. Adapun dalam penyuluhan ada beberapa orang peserta yang mengajukan pertanyaan tentang wabah pandemi covid yang merajalela sekarang ini. Selain itu, untuk hasil pemeriksaan gula darah dan asam urat terhadap warga Desa Imbudee didapatkan hasil untuk gula darah hanya 1 orang yang kadar glukosa dalam darahnya tinggi sedangkan untuk asam urat ada 4 orang dengan kadar uric acid tinggi.

Kegiatan ini juga mendapat dukungan dari bidan desa setempat, karena dapat mendeteksi warga dengan keadaan kadar gula darah dan uric acid yang tinggi sehingga dapat dilakukan pemantauan berkala untuk kesejahteraan kesehatan masyarakat setempat. Adapun luaran yang dicapai dari hasil penyuluhan ini berupa publikasi pada jurnal Rambideun (Jurnal Pengabdian kepada Masyarakat ber ISSN, baik dalam bentuk cetak maupun online) dan dipublikasikan pada web. LPPM Universitas Almuslim.

Berikut rangkaian dokumentasi kegiatan pengabdian masyarakat di Desa Imbudee 
Kecamatan Kutablang Kabupaten Bireuen:

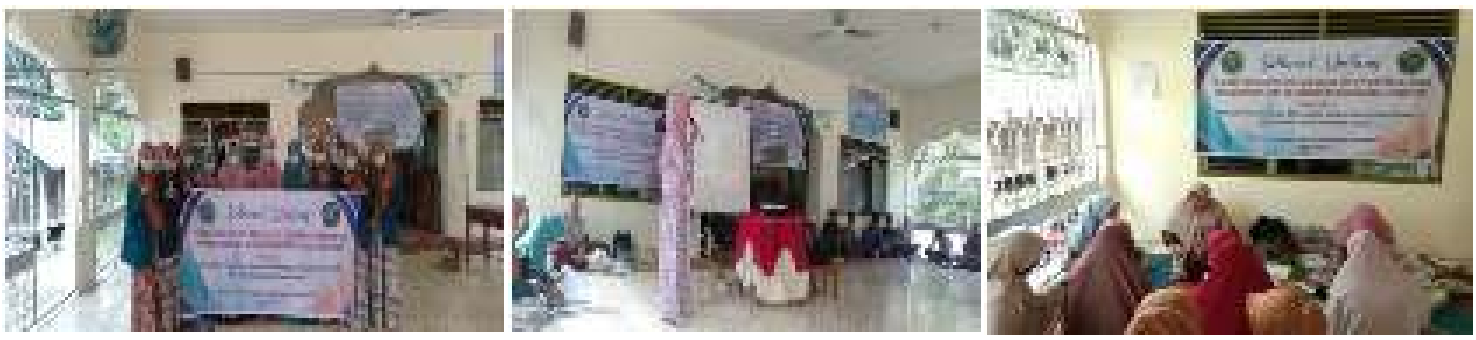

\section{KESIMPULAN DAN SARAN}

Berdasarkan hasil pelaksanaan kegiatan pengabdian masyarakat tentang pencegahan Covid-19 dan pemeriksaan kesehatan gratis di Desa Imbudee Kecamatan Kutablang Kabupaten Bireuen disimpulkan bahwa: 1) masyarakat sudah mengerti dan ingin melaksanakan pencegahan Covid-19 dengan cara jaga jarak, memakai masker dan mencuci tangan dengan benar; 2) dari seluruh masyarakat yang hadir, hanya 27 orang yang beminat melakukan pemeriksaan kesehatan untuk gula darah dan asam urat; 3) hasil yang didapati dari 27 orang yang diperiksa adalah untuk gula darah hanya 1 orang yang kadar glukosa dalam darahnya tinggi sedangkan untuk asam urat ada 4 orang dengan kadar uric acid tinggi; dan 4) bagi masyarakat dengan keluhan gula darah dan asam urat yang tinggi dapat melakukan konsultasi dengan bidan desa untuk mendapatkan penanganan kesehatan yang sesuai.

Adapun saran yang dapat disampaikan setelah kegiatan pengabdian ini, yaitu: 1) diharapkan kepada perangkat desa supaya dapat meningkatkan pelayanan yang paripurna kepada masyarakat, sehingga masyarakat mendapatkan pelayanan yang baik dan menyeluruh; 2) diharapkan kepada masyarakat agar dapat memeriksakan diri sesuai arahan petugas kesehatan, sehingga bisa meminimalisir terjadinya resiko penyakit yang ditimbulkan; dan 3) diharapkan kepada dosen agar kegiatan pengabdian ini dapat dilaksanakan secara berkesinambungan.

\section{UCAPAN TERIMA KASIH}

Ucapan terima kasih disampaikan kepada Bapak Iskandar S.Pd selaku Kepala Desa Imbudee, Nurhidayati, M.PH selaku Direktur Program DIII Kebidanan Universitas 
Almuslim, dosen, mahasiswa dan civitas akademika Universitas Almuslim yang telah banyak memberikan bantuan dalam penyelesaian pengabdian kepada masyarakat ini.

\section{REFERENSI}

Fadli, Rizal. 2020. https://www.halodoc.com/kesehatan/coronavirus

KPCPEN. 2020. https://covid19.go.id/edukasi/materi-edukasi

Marni, Br Karo. 2020. Perilaku Hidup Bersih dan Sehat (PHBS) Strategi Pencegahan Penyebaran Virus Covid-19.

http://proceedings.ideaspublishing.co.id/index.php/hardiknas/article/view/1/1

World Health Organization. 2019. Corona Virus. Retrieved from World Health Organization. https://www.who.int/healthtopics/coronavirus. 